\title{
Cultivation of English Autonomous Learning Ability via Network and Multimedia
}

\author{
H.M. Zhao \\ Teaching and Research Institute of Foreign Languages \\ Bohai University \\ Jinzhou, China
}

\begin{abstract}
Due to the arrival of knowledge economy, it is necessary to learn the knowledge for lifetime. Currently, the autonomous learning ability is poor for the college students during college English learning and they cannot acquire English language knowledge actively. It has become the focus of college English education how to improve the autonomous learning ability of students. In view of the poor autonomous learning ability of students, the author discusses the cultivation of autonomous learning ability for college English learning and proposes some strategies on the reform of English teaching.
\end{abstract}

Keywords-multimedia; autonomous learning; English ability; English teaching

\section{INTRODUCTION}

With the coming of knowledge economy, the knowledge acquired by the students in the undergraduate stage can not meet the needs of society. Therefore, lifelong learning becomes necessary for the personnel of current workplace. It is the major problem for the college English education how to cultivate the English ability of students and make them learn autonomously in the communication of international information so as to acquire the necessary knowledge and skills. At the same time, along with the deepening of teaching reform in college teaching, the concept of learner-centered teaching becomes the mainstream. Based on this teaching concept, it becomes the difficult mission for college English teaching how to cultivate the autonomous learning ability in college English learning. Fortunately, the college English teaching of autonomous learning based on multimedia and network technology can solve this problem quite well. It can change the single mode of traditional teaching, improves the efficiency of English teaching, stimulates the learning enthusiasm of students, and lead them to construct the knowledge structure actively. In Sep. 2007, the Ministry of Education issued "College English Curriculum Requirements", in which some requirements are written as follows. "The colleges should make full use of modern information technology and adopt the English teaching mode based on computer technology, and change the single mode of teacher-centered teaching. The new teaching mode should be based on the modern information technology, especially the network technology, and make the English teaching not be restricted by the space and time and develop toward the individualized and autonomous learning direction." Currently, the teaching practice of college English autonomous based on multimedia and network has been carried out in colleges. Many colleges have invested much capital in the hardware of multimedia and network, and built the local network system and integrated voice classrooms so as to provide a good learning environment of network for students. All these measures are intended to cultivate the autonomous learning ability of students. Due to the lack of guidance of systematic theory on English autonomous learning and teaching, most multimedia network teaching is only in form and appearance. The teaching efficiency is low. The advantages of multimedia and network have not been exerted and consequently it does not promote the autonomous learning of students. Therefore, it becomes the important problem for the current English teaching how to cultivate the autonomous learning ability of students via network technology and realize the transformation of classroom teaching mode.

\section{Present Situation of the College Autonomous LEARNING}

According to the teaching experience of author, the level of autonomous learning is low for the college students and the deficiencies are listed as follows.

(i) Students lack clear learning objectives and plans. In the realization of the learning goals, students generally have no plans on autonomous English learning and they perform poorly when setting the learning goals according to their own situations. Generally, they lack the initiatives and enthusiasm of autonomous learning. In addition, the students perform poorly on the overall planning of distribution of learning time.

(ii) The students do not well know the autonomous learning strategies and the applications of strategies are not balanced for the students during the exercise of listening, speaking, reading and writing. They can not use the strategies skillfully. For example, the application of strategies on writing is not as good as that of reading comprehension. This is because that reading comprehension occupies the large proportion in CET4 or CET6. Students get more exercise on reading comprehension while they lack the exercise on listening, speaking and writing.

(iii) In the process of extracurricular English learning, students do not take the initiatives to practice English and they cannot well use the English learning resources around. Also the students do not consciously use the new knowledge acquired in the language practice and at the same time, they do not effectively cooperate with others in learning. For example, in the language learning, neither do they look for the partners of oral communication, nor do they exchange the learning experience with others students. 


\section{CONCEPTS OF AUTONOMOUS LEARNING}

In his book entitled 'Autonomy and Foreign Language Learning', Holec introduced the concept of 'autonomous learning' in the language learning.[1] $\mathrm{He}$ defined the autonomous learning as the ability to take charge of one's own learning. Dickinson held that the autonomous learning is not only a learning attitude but also the ability to learn independently. Littlewood, a linguist, defined the autonomous learning as 'the desire and ability to make a choice independently'.[2] Zimmermann, an American expert on autonomous learning, held that autonomous learning mainly involved six aspects, namely, why to learn (motivation), how to learn (method), when to learn (time), what to learn (learning outcomes), where to learn (environment), which to learn with (sociality). Although the foreign linguists have different perspectives and opinions on autonomous learning and their definitions on autonomous learning are also different, we still conclude that autonomy is the learning ability or learning behavior in autonomous learning. It means that the students arrange their own learning activities and are responsible for their own learning. Chinese linguist named Shu Ding Fang also concluded that three aspects should be included in the autonomous learning. (1) Attitude. Learners take charge of their own learning and are actively engaged in learning activities. (2) Ability. It ensures that the learners can complete their learning tasks independently. 3) Environment. Plenty of opportunity should be given to the learners to exercise and be responsible for their own learning.

Autonomous learning is the ability to take charge of or manage one's own learning. This means that the students partially or completely have the rights to decide the matters that used to be dealt with by the teacher, e.g. setting the learning goal, setting the learning content and progress, choosing the learning method and skills, monitoring the acquisition process, assessing and evaluating the learning. Therefore, the autonomous learning is the ability to reflect critically and make decision and act independently. Students are always in the position of main body during the autonomous learning and they take charge of their learning and decide the learning content, method and progress. In this process, the students not only acquire the knowledge but also exert the abilities of independent thinking and deciding. This cultivates the consciousness of cooperation and innovation and also builds the confidence and self-esteem of students.

\section{AutONOMOUS LEARNING OF COLLEGE ENGLISH UNDER THE NETWORK AND MULTIMEDIA ENVIRONMENT}

The hardware of network and multimedia is quite ready for autonomous learning. This provides the technology foundation for the autonomous learning of college English. Modern technology of multimedia provides the learner-centered platform for the autonomous English learning. Under the environment of network, autonomous English learning has the main characteristics as follows. (1) Open and virtual. Network can transcend the constraints of time and space and provides many English learning resources. The students can learn the language through the network in different places of campus. At the same time, the technologies of multimedia and network provide the students with the colorful virtual environment. This enhances the interest and initiatives of learning. Also, the network provides convenience for study and discussion. In the network the group or one-to-many discussion is much convenient. (2) Independent and individual. Network environment provides the students with various options of learning. The students can choose the learning content and arrange the learning time according to their own situation. Students can set the learning goal for themselves and get the feedback by self-testing via the network. This can improve the ability of autonomous learning as well as the level of foreign language. (3) Interesting and initiative. The technologies of network and multimedia provide the learners with the vivid graphics and videos. This stimulates the enthusiasm and initiatives of learning for students. At the same time, the resources in network provide the opportunity to expand the knowledge scope of students and improve the learning interest of students. (4) Change of traditional teaching mode. Teachers transform from the traditional leader of classroom to the guider of learning. The students become the main body of learning activities. In learning, the teacher helps the students to realize the construction of knowledge structure. (5) Change of teaching mode and method. Autonomous learning in network will change the mode of traditional teaching mode, where the teacher teaches for most class time, and establish the studentcentered personalized learning mode. It can form the new teaching mode characterized by learning through multimedia and network. In the new teaching mode, the portion of autonomous learning will increase up to $30 \%-50 \%$ in the total learning activity. Students not only use the computer, local network, campus network or the Internet to practice listening, but also complete the tasks of reading, writing and translating by computer.

\section{STRATEgIES ON CULTIVATION OF ENGLISH ABILITY OF AUTONOMOUS LEARNING}

Although the network has huge advantages in English learning, the learners must know how to learn using it. Then they can learn through the network autonomously. That is to say, the learners must master certain learning strategies and then use these strategies effectively to learn language knowledge in the network.

The autonomous learning ability in the network can be cultivated via various teaching methods. For example, it can be trained by direct teaching or guiding reflection and metacognitive discussion. The autonomous learning ability can also be obtained by direction demonstration or reflective analysis. In teaching, the teacher guides the students to experience the three phases, i.e. the phases of being willing to learn, able to learn, and happy to learn.

(i) Cultivation of the awareness of autonomous learning. A linguist named Cohen said that the success of language learning depends on the learner himself,[3] and also the factors of learner as well as the ability to make full use of learning opportunities. English is an applied discipline, and it requires the students to use the language to communicate with others. Learners should fully realize that not only the language knowledge but also the language skills are emphasized in the college English learning. This means that the abilities of listening, speaking, reading and writing are fully developed and 
the comprehensive abilities are improved. The improvement of English ability can depend on not only the instruction of teacher in classroom but also the learning via network to expand the knowledge scopes. In teaching via network, the teacher should guide the students to carry out the specific training through the network. The teacher should make the students to realize that autonomous learning can better improve the English ability. At the same time, the teacher should guide the students to learn autonomously and individually according to their levels and situations, and praises the students for their successful learning timely. This can enhance the confidence and self-efficacy of students in autonomous learning, and therefore cultivates the learning motivation and consciousness of autonomous learning.

(ii) Choosing appropriate learning strategies. The network provides the students with the system of knowledge and environment of interactive learning. However, the effect of autonomous learning in the network depends on the choice of learning strategies. The students must master certain learning strategies and apply effectively the strategies into learning. Studies show that successful learners are often those who use the language learning strategies quite well. Language learning strategies include cognitive strategies and metacognitive strategies. The cognitive strategies can be listed as follows. (1) Rehearsal strategies. Namely, the learners repeat the information many times so as to remember the information in the learning. This strategy is applicable to the situation of previous knowledge shortage. (2) Strategy of finish machining. The students solve the problems by seeking the answers from network. This can enhance the memory of knowledge and expands the learning scope. (3) Organization strategy. The knowledge learned from both class and network is organized by the learners into the inner knowledge structure. The metacognitive strategies include the following terms. (1) Selfmonitoring. That is, the learner should take charge of the learning activity of his own and assesses the learning process by himself. (2) Self-instruction. Learners present the learning methods and steps of network by constant mode, in order to guide themselves. (3) Self-evaluation. Learners evaluate the effect and progress of network-learning by themselves. In fact, appropriately using of learning strategies can help the students to improve the ability of autonomous learning in the network environment. [4]

(iii) Measures of class teaching via network and multimedia. The teacher uses the multimedia to carry out the group teaching. Teacher uses a series of multimedia equipment to show the relevant contents to the students and makes more detailed explanation on them. The learning activities include the forms of question and group discussion. In group activities, the representatives will introduce the discussion results of their groups to the class. All the students put forward their questions to the representatives according to their discussions and exchange with them. Of course, the students carry out the above communications using the multimedia equipment. In teaching, the teacher organizes the teaching activity and tries to stimulate the enthusiasm of discussion and cooperation of students. Class teaching is carried out in task-based teaching mode and the teacher should inspire the students to think about the problems and encourages each student to participate in discussion. After the presentation of groups, the teacher should evaluate the performance of each group and comments on the preparation, expression, and degree of participation of groups. At the same time, the teacher should summarize the results of discussion and explains and analyzes the problems. This can clarify the emphases and difficulties of learning as well as enable students to better understand the problems.[5]

(iv)Exerting the helper role of teacher. Under the environment of network, autonomous learning is not the learning without teacher, but the one in which the teacher plays the new role. Teaching under network environment will inevitably promote the change of traditional teaching mode. That is, the new teaching mode should be student-centered and uses the network to promote the knowledge construction of students, and also guides the students to build the autonomous learning mode of their own according to their differences and preferences. Along with the wide application of network and multimedia in class teaching, the teacher is no long the traditional disseminator of knowledge, but the helper of knowledge construction as well as the guider in the autonomous learning of students.

In the network environment, teacher should design the teaching content in order to develop and cultivate the autonomous learning ability of students. Teacher should pay attention to stimulate the interest of students and help the students form a clear learning motivation. In teaching, the teacher assigns the task and leads the students to set the learning goals for themselves. The teacher leads the students to learn through network and summarizes the successful cases and examples in the autonomous learning. When the students encounter difficulties in learning, the teacher should give his advice and guidance to the students and encourage them to continue to learn. The teacher should pay attention to the subjective role of students in the construction of knowledge structure.

\section{CONCLUSION}

The coming of information technology represented by network and multimedia provides the supports of hardware to the autonomous learning of college English. It makes the autonomous learning much easy and feasible. Students can make their choice on the time, place, and difficulty for their learning. Therefore, the technologies of network and multimedia are beneficial to the cultivation of autonomous learning ability. Teacher should cultivate the autonomous learning awareness of students and stimulates their learning motivations through network and multimedia. The teacher should teach the necessary learning strategies to the students and play the roles of learning partner and helper of students in autonomous learning. In autonomous learning, the teacher actively leads the students to construct the knowledge structure.

\section{ACKNOWLEDGEMENT}

This work is part of the project of Research on Task-based English Teaching Mode Based on Constructivism Theory. The work has been supported from the fund of Liaoning Provincial Association of Social Sciences (No. 2015lslktziwx-03). 


\section{REFERENCES}

[1] Holec H, Autonomy and Foreign Language Learning. Oxford: Pergamon Press, 1981

[2] Littlewood, W. Autonomy: an anatomy and a framework, System 24, pp. 427-435, 1996

[3] Cohen, A. Language Learning: Insights for Learners, Teachers, and Researchers, New York: Newbury House, pp.15-16, 1990.

[4] Lan, W. Y. The effects of self-monitoring on students' course performance, use of learning strategies, attitude, self-judgment ability, and knowledge representation, Journal of Experimental Education, 64(2), pp. 101-115, 1996.

[5] Long, M. Task, group, and task-group interactions, University of Hawaii Working Papers in ESL, 8, pp.1-26, 1989. 